\title{
Evaluation as a Tool for Teaching and Learning in Selected Technical and Vocation Institutions in Ibadan
}

Ogechukwu Rose Appah리 ,Tokede Abiodun Morenike², Owolola Ouwaseun Iyanuoluwa ${ }^{3}$, Tunde-

\author{
Francis Anne Abuekin ${ }^{4}$, Ibode Rebecca Titilope ${ }^{5}$
}

Article History:

Received 28.12.2020

Received in revised form

05.08.2021

Accepted

Available online

01.10.2021

\begin{abstract}
The study was carried out to explore the evaluation practices carried out in selected technical and vocational institutions. This is a survey study conducted in Ibadan, Oyo State Nigeria. It involved three hundred (300) students and one hundred and twenty (120) teaching staff. The study was guided by three (3) research questions. Data were collected using two questionnaires titled: Students' questionnaire on Evaluation methods (SQEM) and teaching staff perception questionnaire on the role of Evaluation (TSPQRE). Data collected were analysed using descriptive (frequency, percentage, mean and Standard Deviation) and Pearson moment correlation. The result of the study revealed that most of the students agreed that evaluation carried out in their institution is mostly summative evaluation where students are assessed only at the end of the semester or mid semester tests. Findings of the study also showed that teaching staff agreed that evaluation is a means of improving teaching and learning in schools and there is also a relationship between teaching staff working experience and their perception of evaluation as a means of improving teaching and learning. It was recommended that teaching staff should use different methods to evaluate their students in order to improve teaching and learning in their institutions
\end{abstract}

(C) IJERE. All rights reserved

Keywords: Perception, learning, evaluation, institution, summative evaluation

\section{INTRODUCTION}

Understanding of students learning should be paramount to teachers so they can focus their efforts on key areas that need to be improved upon. To understand students leaning, there is need to evaluate teaching and learning activities done in any educational system. Technical and vocational education and training are living experiences meant to be imparted to an individual systematically in order to get him/her adequately equipped for a good employment in a recognized occupation immaculate (Eyong, Ugada \& Aminu, 2020; Hariyani, Ahmad \& Marsitin, 2021; Karagoz, 2021). However, technical and vocational education being a vital instrument for sustainable developmental and societal transformation; there is need for stakeholders to seek ways of improving the quality and impact of technical and vocational education in Nigeria. This can be achieved through evaluation of the programmes. Evaluation of school teaching and learning activities is indispensable for the achievement of excellence in the educational sector. This is because in any educational programme, both the learner and facilitator enter a programme expecting to come out with something beneficial and satisfying. According to Asuru (2009), the main aim of educational programme is to enable the subject, client and recipients acquire attitudes, knowledge, skills and competencies for harnessing human and material resources so as to improve their living standard. The school system or institutions of learning have a great role to play in achieving this. This fact is corroborated by Yoloye (2008) who reported that educational evaluation is essential for decision making, identifying and analysing relevant data upon which decisions can be based on. He went further to describe educational evaluation as the process of monitoring the implementation process of educational programme to ensure that it is appropriately done, and identifying objectively the impact or outcomes of decisions. To verify whether the learner, teacher and school have achieved the goals and objectives of educational programme, there is need for people to reflect, make judgments and form conclusion about actions taken on the educational programme. This explains why some researchers like Onunkwo (2008) defined evaluation as a systematic process of collecting, analysing and interpreting information derived from other assessment activities to determine the extent to which students are achieving instructional objectives. Chippatiso and Marango (2012), also posited that evaluation is a conscious and purposeful exercise in which questions are often asked to determine the effectiveness, impact, achievements and benefits of a programme. In educational system, how much a student has succeeded in learning can be determined through evaluation. Evaluation therefore, is a stepping stone to improving any programme including educational programme. Educational evaluation as defined above in this study, provides adequate and effective feedback on students' achievement not only in the cognitive area, but also in the areas of interest and manipulative skill. It also provides feed-back from students to the teacher about the effect of the teacher's teaching method. In addition, it provides feedback from the teachers to the parents about their wards' performance. It provides feed-back from school administrators to the policy makers so as to determine the success of the programme. 
Evaluating the programme in any school becomes expedient in order to determine whether the educational system is performing its function as expected or not. This is in line with the opinion of Lina Vyas (2004) who reported that, evaluation is the most important means to determine the effectiveness of training. This implies that if a programme has objectives and the managers of the programme are committed to achieving these objectives, it is essential that evaluation of the programme be undertaken in order to realise the programme objectives. So, educational programme is said to be effective when training outcome matches the objectives. There are many types of evaluation, depending on the purpose, timing, and procedures used. The main types of evaluation identified and used in the classroom are

\section{i. Diagnostic evaluation \\ ii. Formative evaluation, and \\ iii. Summative evaluation}

Diagnostic (initial) Evaluation - Diagnostic test is a form of evaluation of the students that helps the teacher to determine students' individual strength and weakness and use the information to subsequently improve students' learning and guide further learning (Jang 2008 \& Department of Education 2013). Diagnostic evaluation is therefore, very important for teachers because it helps them to know the entry behaviour of the students, that is, whether they are ready to learn and if they have the basic skills and information required to continue the new learning. It also helps the teacher to know the level to which the students have already learnt a particular unit. Diagnostic evaluation also assists the teacher to classify the students according to their level of mastery and in turn help to work out a remedial instruction for slow learners or low achievers.

Formative evaluation is performed to examine various aspects of an ongoing program in order to make changes as the program is being implemented. Formative evaluation is carried out within or during the development of a course of programme. Thus, this type of evaluation is conducted for the purpose of improving the programme Ayodele, Adegbite \& Adewale (2009). In school system, it is used for improving the performance of the teacher, student and curriculum development. It is used in determining the mastery level of the learner and the remedy to make. Formative evaluation helps the teacher to see the efficiency of the teaching method so that he/she can improve his/her teaching. It will equally provide feedback on the effectiveness of the course contents and teaching materials used. Formative evaluation is such that data are collected and analyzed at a time when program changes can be made to ensure that the quality of the program implementation is maintained throughout.

Summative (Final) Evaluation - Summative evaluation is conducted for the purpose of accountability which requires determining the overall effectiveness or merit and worth of an evaluation programme. The summative evaluation is an evaluation at the end of a course or programme and it has thrust in judgement of programme after they have been put in place Onuogha (2011). This implies that summative evaluation is carried out at the end of a course or programme for grading, certification and placement. Summative evaluation is conducted for the purpose of documenting the results of a program. The purpose of summative evaluation is to find out if a programme outcome is what it was set out to achieve; that is, it helps to make decision on the students. However, it can also be used in making decisions regarding the future of the students or the programme being developed; whether it should be continued or terminated, replicated or disseminated.

Considering the evaluation types described above, students can be evaluated using assignment, classroom quizzes and examinations, discussion in the class, projects, oral questions, questionnaire, interview and even observation. To improve the skill acquired by the students during the process of learning, their learning difficulties need to be identified, corrected and reinforced. There is also the likelihood that if students' learning is adequately evaluated regularly during teaching and learning process; and feedback and remediation provided, then, the students' level of performance and skill acquisition will improve. Furthermore, to ensure that the enabling environment is provided to meet the need and

aspiration of learners, it becomes imperative to carry out evaluation so as to ascertain the achievement of the learning goals of the learners and their academic standard (Okpala, Onocha and Oyedeji 1993). Also providing feedback to the students when knowledge of their performance in tests and assignments in both theoretical and practical works is tested is very essential to them. This feedback on the performance of tests and assignments enables the students to structure their understanding and make them build more ideas. According to Gronlund and Linn (1990), feedback provides reinforcement and correctional information. For instance, a student who is informed of his/her performance in test or assignment would begin to develop 
interest in the subject and may on his own try to explore other means of performing better in subsequent tests and assignments.

Remediation is the process of leading learners to be aware of their errors and provide corrective measures that will tackle deficiencies in the learners either individually or as a group. Students that undergo remediation accomplish greater number of objectives than students who participate in an instructional programme that does not include remediatial activities (Swanson \& Denton 1977 as cited by Ajogbeje \& Alonge 2012). Also Ajogbeje and Alonge (2012), carried out a study on effect of feedback and remediation on students' achievement in junior secondary Mathematics, their findings showed that students provided with feedback and remediation perform better than students provided with feedback without remediation.

Despite the importance of evaluation in improving leaning and teaching, some lecturers and instructors hardly discuss students' performance with the students with the view of helping them identify their errors and weaknesses and for possible remedial to take place. However, the main objective of evaluation for learning improvement might not be achieved. Hence, this study examined how students' works are evaluated and teaching staff perception and awareness of evaluation as a means of improving teaching and learning at tertiary Technical and Vocational Education and as a means of achieving educational goals.

This study sought to answer the following research question:

1. How is students' evaluation carried out in Federal College of Forestry?

2. What is the teaching staff perception of evaluation as a means of improving teaching and learning in technical and vocational institutions?

3. What is the relationship between teaching staff working experience and perception of evaluation as a means of improving teaching and learning?

\section{Methodology}

This study adopted descriptive and correlational survey research. Descriptive and correlational survey were adopted for this study. Descriptive survey study is a study where data collected are described in a systematic manner based on the characteristics, features and facts about a given population. Correlational survey seeks to establish the relationship that exists between two or more variables. It does not involve manipulation of variables, rather, it entails the collection of data to describe existing phenomena. The study was carried out in Ibadan, Oyo State Nigeria. The target population for this study comprised of selected technical and vocational tertiary institutions. Purposive sampling was used to select the three Federal technical and vocational tertiary Institutions in Ibadan. Federal College of Forestry, Federal College of Animal Health Production and Federal College of Agriculture. Simple random sampling technique was used to select three hundred (300) students, one hundred students from each of the three colleges. Two instruments were used in carrying out the study, these are (a) Students' questionnaire on Evaluation methods used (SQEM) (b)Teaching staff perception questionnaire on the role of Evaluation (TSPQRE)

\section{Students' Questionnaire on Evaluation Methods (SQEM)}

This instrument developed by the researchers consists of two sections A and B. Section A is made up of students' demographic variables and section B consists of twenty (20) items to measure the extent to which the students are evaluated, with responses measured on 4 points Likert scale from Strongly Agree, Agree, Disagree and Strongly Disagree. This instrument was validated using fifty (50) students who are not included in this study. The face and construct validity of the instrument were obtained and internal consistence and reliability of the instrument were established using Cronbach Alpha giving the value of 0.82 .

\section{Teaching staff perception questionnaire on the role of Evaluation (TSPQRE)}

This instrument also developed by the researchers was made up of two sections A and B. Section A elicited information on the demographic data of the teaching staff while section B consisted of twenty (20) items with responses measured on 4 points Likert scale from Strongly Agree, Agree, Disagree and Strongly Disagree to measure lecturers and instructors' perception on the role of evaluation in improving teaching and learning in technical and vocational institutions. The items were validated and the reliability coefficient was 0.80 . The instrument was administered by the researchers. Data collected were analysed using descriptive statistics (frequency, percentage, mean and standard deviation) and Pearson moment correlation. At the time of the analysis, all the strongly agree and agree responses were lumped together under agree and all the strongly disagree and disagree were lumped together under disagree. 


\section{Results}

\section{Research question 1.}

Table 1. Mode of assessments of students in tertiary technical and vocational institution

\begin{tabular}{|c|c|c|c|c|c|}
\hline $\mathrm{S} / \mathrm{N}$ & ITEMS & DISAGREE & AGREE & MEAN & S/D \\
\hline 1 & $\begin{array}{l}\text { Class work after each class to } \\
\text { know the extent we have learnt }\end{array}$ & $181(60.3 \%)$ & $119(39.7 \%)$ & 1.40 & .490 \\
\hline 2 & Assignment after each class & $157(52.3 \%)$ & $143(47.7 \%)$ & 1.48 & .500 \\
\hline 3 & Test after each topic & $205(68.3 \%)$ & $95(31.7 \%)$ & 1.32 & .466 \\
\hline 4 & $\begin{array}{l}\text { Test once in a semester and } \\
\text { examination at the end of the semester. }\end{array}$ & $152(50.7 \%)$ & $148(49.3 \%)$ & 1.49 & .501 \\
\hline 5 & $\begin{array}{l}\text { Tests twice in a semester and } \\
\text { examination at the end of the semester. }\end{array}$ & $111(37.0 \%)$ & $189(63.0 \%)$ & 1.63 & .484 \\
\hline 6 & $\begin{array}{l}\text { Asking random questions in the } \\
\text { class to know the extent we have learnt } \\
\text { each topic. }\end{array}$ & $162(54.0 \%)$ & $138(46.0 \%)$ & 1.46 & .499 \\
\hline 7 & $\begin{array}{l}\text { Give us opportunities to ask } \\
\text { questions in class and to contribute to } \\
\text { class discussion. }\end{array}$ & $135(45.0 \%)$ & $165(55.0 \%)$ & 1.55 & .498 \\
\hline 8 & $\begin{array}{l}\text { We are given practical works at } \\
\text { the end of each topic }\end{array}$ & $7(2.3 \%)$ & $293(97.7 \%)$ & 1.40 & .491 \\
\hline 9 & $\begin{array}{l}\text { Re-teaching topics we don't } \\
\text { understand to improve our learning }\end{array}$ & $198(66.0 \%)$ & $102(34 \%)$ & 1.39 & .459 \\
\hline 10 & $\begin{array}{l}\text { Opportunities to make class } \\
\text { presentations }\end{array}$ & $193(64.0 \%)$ & $107((35.7 \%)$ & 1.36 & .480 \\
\hline 11 & $\begin{array}{l}\text { Feedback from our tests scores } \\
\text { or assignments }\end{array}$ & $203(67.7 \%)$ & $97(32.3 \%)$ & 1.32 & .469 \\
\hline 12 & $\begin{array}{c}\text { Discuss our grades and } \\
\text { assignments with us }\end{array}$ & $226(75.3 \%)$ & $74(24.7 \%)$ & 1.75 & .432 \\
\hline 13 & $\begin{array}{l}\text { Give prompt feedback on our } \\
\text { academic performances }\end{array}$ & $81(27 \%)$ & $219(73.0 \%)$ & 1.73 & .445 \\
\hline 14 & $\begin{array}{l}\text { Give us group assignment that } \\
\text { will require contribution of each } \\
\text { student }\end{array}$ & $112(37.3 \%)$ & $188(62.7 \%)$ & 1.62 & .487 \\
\hline 15 & $\begin{array}{l}\text { Make us work with our course } \\
\text { mates outside of class to prepare for a } \\
\text { new topic }\end{array}$ & $128(42.7 \%)$ & $172(57.3 \%)$ & 1.58 & .495 \\
\hline 16 & $\begin{array}{l}\text { Use different methods to make } \\
\text { us learn }\end{array}$ & $176(58.7 \%)$ & $124(41.3 \%)$ & 1.32 & .468 \\
\hline 17 & $\begin{array}{l}\text { Encourage discussion and } \\
\text { response to questions }\end{array}$ & $130(43.3 \%)$ & $170(56.7 \%)$ & 1.41 & .493 \\
\hline 18 & $\begin{array}{l}\text { Challenge students to do their } \\
\text { best in the course }\end{array}$ & $190(63.3 \%)$ & $110(36.7 \%)$ & 1.37 & .483 \\
\hline 19 & $\begin{array}{l}\text { Make themselves accessible } \\
\text { outside the class }\end{array}$ & $138(46.0 \%)$ & $162(54.0 \%)$ & 1.54 & .499 \\
\hline 20 & $\begin{array}{l}\text { Assessments as done in my } \\
\text { institution has helped improve our } \\
\text { leaning outcome }\end{array}$ & $152(50.7 \%)$ & $148(49.37 \%)$ & 1.51 & .501 \\
\hline
\end{tabular}

Table 1 shows that $78 \%$ of the students indicated that they are assessed through test twice in a semester and examination at the end of the semester. $62 \%$ of the students agree that they are given group assignment that will require contribution of each students. $97.7 \%$ of the students agreed that they are given practical works at the end of each topic. In addition, oover $70 \%$ of the students disagree that their teaching staff re-teach topics they don't understand, give them feedback from their tests and assignments, discuss their grades and assignments with them, give prompt feedback on their academic performances. $63 \%$ of the students also indicated that assignments and tests are not given to them at the end of each class or each topic. However, 
only $50.7 \% \%$ of the students indicated that the evaluation methods used for them improve their learning outcome.

\section{Research question 2:}

Table 2 Teaching staff perception of students' evaluation as a means of improving teaching and learning.

\begin{tabular}{|c|c|c|c|c|c|}
\hline $\mathrm{S} / \mathrm{N}$ & ITEMS & DISAGREE & AGREE & MEAN & $\mathrm{S} / \mathrm{D}$ \\
\hline 1 & $\begin{array}{l}\text { Improve efficiency and effectiveness of the } \\
\text { students }\end{array}$ & $9(7.5 \%)$ & $111(92.5 \%)$ & 1.79 & .408 \\
\hline 2 & $\begin{array}{l}\text { Improve efficiency and effectiveness of the } \\
\text { teaching staff }\end{array}$ & $25(20.8 \%)$ & $95(79.2 \%)$ & 1.93 & .264 \\
\hline 3 & Diagnoses students' problem areas & $23(19.2 \%)$ & $97(80.8 \%)$ & 1.81 & .395 \\
\hline 4 & $\begin{array}{l}\text { Determine effectiveness of instructional } \\
\text { methodology being used }\end{array}$ & $42(35.0 \%)$ & $78(65.0 \%)$ & 1.65 & .479 \\
\hline 5 & $\begin{array}{l}\text { Determine if the resources available are } \\
\text { adequate }\end{array}$ & $25(20.8 \%)$ & $95(79.2 \%)$ & 1.79 & .408 \\
\hline 6 & $\begin{array}{l}\text { Maintain the standard of educational } \\
\text { program }\end{array}$ & $23(19.2 \%)$ & $97(80.8 \%)$ & 1.81 & .395 \\
\hline 7 & Improve students' learning outcome & $33(27.5 \%)$ & $87(72.5 \%)$ & 1.77 & .425 \\
\hline 8 & $\begin{array}{l}\text { Identify students' area of weakness and } \\
\text { provide help }\end{array}$ & $28(23.3 \%)$ & $92(76.7 \%)$ & 1.66 & .470 \\
\hline 9 & Provide feedback to students & $39(32.5 \%)$ & $81(67.5 \%)$ & 1.66 & .476 \\
\hline 10 & Form value judgement about the students & $34(28.3 \%)$ & $86(71.7 \%)$ & 1.72 & .453 \\
\hline 11 & $\begin{array}{l}\text { Identify areas of improvement in order to } \\
\text { realize educational goals }\end{array}$ & $25(20.8 \%)$ & $95(79.2 \%)$ & 1.21 & .408 \\
\hline 12 & Assess the performance of the students & $48(40.0 \%)$ & $72(60.0 \%)$ & 1.40 & .492 \\
\hline 13 & $\begin{array}{l}\text { Provide quality information to students } \\
\text { about their learning }\end{array}$ & $32(26.7 \%)$ & $88(73.3 \%)$ & 1.73 & .444 \\
\hline 14 & $\begin{array}{l}\text { Use different teaching methods to make } \\
\text { students learn }\end{array}$ & $34(28.3 \%)$ & $86(71.7 \%)$ & 1.72 & .453 \\
\hline 15 & $\begin{array}{l}\text { Give prompt feedback on the students' } \\
\text { academic performance }\end{array}$ & $14(11.7 \%)$ & $106(88.3 \%)$ & 1.88 & .322 \\
\hline 16 & $\begin{array}{l}\text { To make use of available resources } \\
\text { effectively }\end{array}$ & $45(37.5 \%)$ & $75(62.5 \%)$ & 1.43 & .496 \\
\hline 17 & $\begin{array}{l}\text { Keep work on track and know when } \\
\text { things are going wrong }\end{array}$ & $69(57.5 \%)$ & $51(84.2 \%)$ & 1.48 & .502 \\
\hline 18 & Know students' area of weaknesses & $35(29.2 \%)$ & $85(70.8 \%)$ & 1.71 & .456 \\
\hline 19 & Challenge students to do their best & $16(13.3 \% \%)$ & $104(86.7 \%)$ & 1.62 & .488 \\
\hline 20 & $\begin{array}{l}\text { Find out if capacity available is sufficient } \\
\text { and appropriate }\end{array}$ & $70(58.3 \%)$ & $50(41.7 \%)$ & 1.87 & .341 \\
\hline
\end{tabular}

Table 2 shows that majority of the respondents, perceived that students' evaluation is a means of improving teaching and learning in technical and vocational institution. This is shown in all items except item 20 where they disagreed that students' evaluation cannot be used to find out if capacity available is sufficient and appropriate. This implies that teaching staff have high perception rate towards the effect of students' evaluation on improving teaching and learning in the institution.

\section{Research Question 3}

What is the relationship between teaching staff working experience and their perception of evaluation as a means of improving teaching and learning?

\section{Correlations}

\begin{tabular}{ccccl}
\hline $\mathrm{S} / \mathrm{N}$ & Result relationship & Correlation & Sig & P-Value \\
1 & Working Experience and Perception & 0.201 & 0.027 & 0.05 \\
\hline
\end{tabular}

* Correlation is significant at the 0.05 level.

Table 3 shows a correlation coefficient (r) of 0.201 which reveals that there is positive significant relationship between teaching staff working experience and their perception of evaluation as a means of improving teaching and learning in technical and vocational institutions.

\section{Discussion}


The findings from the study revealed that majority of the students revealed that the teaching staff assess them by giving them written tests twice in a semester and examination at the end of the semester work. They also indicated that tests and assignments are not given to them at the end of each class or topics to access the extent to which they have learnt. This is an indication that evaluation carried out in tertiary institution is summative evaluation where students are assessed only at the end of the semester or mid semester tests. This finding supports the work of Onuka and Durowoje (2011) on continuous assessment for improved higher education learning achievement, they reported that in Nigerian schools, students are commonly assessed through written test and examination only. The result also showed that majority of the teaching staff do not always give feedback to students concerning their performance on tests and assignments. This is an indication that the students are not always given feedback concerning their tests and assignments, even when the feedbacks given to them are not done promptly. The study also revealed that almost all the students indicated that they are given practical works at the end of each topic. This is attributed to the fact that technical and vocational institution is practical oriented. This is supported by the goal of technology education at tertiary education stipulated in the National Policy of Education (2013) that technical and vocational institution is a vital education that leads to practical and applied skills as well as basic scientific knowledge. The finding also revealed that up to $50 \%$ of the students claimed that the way assessment is carried out in the school has not improved their learning.

The results from table 2 revealed that students' assessment play enormous role in teaching and learning process in technical and vocational institutions. This is because majority of the teaching staff perceived that evaluation of students play vital role in improving efficiency and effectiveness of the students, the teaching staff and instructional methodology used in the schools. This is corroborated by Lynch, (2018), that continuous assessment provides day to day feedback about learning and teaching process, reinforce the efficacy of teaching and learning, and also encourages the understanding of teaching as a formative process that evolves overtime with feedback and input from students. They also agreed that it helps to identify students' area of weakness and to provide quality information to students about their learning. Hence,( evaluating students will help teaching staff know how far the students are performing and help them give more time to weaker students to assist them. This agrees with Ajuonuma and Oguguo (2015) that continuous assessment of students improves students' performance. The finding also supports Chan, Kennedy, Yu and Fok (2006) that information gathered in evaluations should be used to improve students learning.

Table 3 also revealed that relation exist between teaching staff working experience and their perception of evaluation as a means of improving teaching and learning in technical and vocational institutions. The teaching staff experience has a significant contribution to the way they perceived evaluation as a means of improving teaching and learning in technical and vocational institutions. This finding confirms Ewetam and Ewetam (2015), Akinsola (2010) who found that teachers' teaching experience correlated significantly and positively with students' academic performance. It also agrees with Appah and Adeleke (2016) that teaching experience contributed significantly to student establishment skill acquisition.

\section{Conclusion}

The findings of the study showed that many teaching staff perceived evaluation as means of improving teaching and learning in technical and vocational institution. Hence there is need for the school authorities to ensure monitoring and implementation of different modes of evaluation in assessing students. This is necessary as perceived by the teaching staff that evaluation provides information about teaching and learning and can be used to diagnose learners and teaching staff strengths and weaknesses, provide feedback on teaching and learning and the appraisal of effectiveness of instructional materials used by teaching staff during teaching and learning.

This study was limited to only three federal colleges in Ibadan, Oyo state, Nigeria. There are many other technical and vocational Institutions in the state, both Federal, state and private owned. Further research can be conducted focusing on other technical and vocational institutions. Another constraint was in data collection, it took time to convince the teaching staff of the colleges included in this study that the information was for research purpose only and that any information obtained from them will not implicate them. Based on the findings of this study, the following recommendations are made: There is need for teaching staff to constantly evaluate students' work in technical and vocational tertiary institutions in order to improve students' learning. Teaching staff should ensure that they use different methods such as tests, assignments, classwork project works, giving students opportunity to ask questions, oral questions to evaluate students. 
There should be training for the teaching staff to educate especially those staff who are new on the importance of students' constant evaluation in improving teaching and learning. In every test, assignment, class work and project given to the students, prompt feedback should be given to the students to enable them know their weak areas to enable them improve on them before the final examinations.

\section{Reference}

Ajogeje, O. J. \& Alonge, M.F. (2012). Effect of feedback and remediation on student's achievement in junior secondary school mathematics. International Education Studies, 5. http://dx.doi.org/10.5539/ies.v5n5p153.

Ajuonuma, J. O., \& Oguguo, C.E. (2015). Teachers' perception of the impact of continuous assessment strategies on students' learning in secondary schools. Nigerian Journal of Educational Research and Evaluation, 14(2), 127-137.

Asuru, V.A. (2009, November 24 - 27). Programme evaluation: An imperative for successful basic education programme in Nigeria. [Proceedings of International conference on research and development]. University National Du Benin, Cotonou. Republic of Benin 2 (24), 10-14.

Ayodele, S.O., Adegbile, J.A., and Adewale, J.G., (2009). Evaluation studies. Published by Powerhouse Press and Publishers Ibadan, 16-18. ISBN 978-35794.

Chan, J.K., Kennedy, J.K., Yu, F. W. and Fok, P. (2006). Assessment policy in Hong Kong: Implementation Issues for New Forms of Assessment [Paper presentation]. The 32nd Annual Conference of International Association for Education Assessment, Singapore, 21-26.

Department of Education (2013). Diagnostic assessment. www.education.nt.gov.au/parents.com.

Eyong,E,I., Ugada,C. \& Aminu,A. (2020). Indicators of improved achievement of students' in mathematics. The Universal Academic Research Journal,2(1), 29-37

Ewetan, T.O., \& Ewetan O.O. (2015). Teachers' teaching experience and academic performance in mathematics and english language in public secondary schools in Ogun State, Nigeria. International Journal of Humanities Social and Science Education (IJHSSE), 2(2), 123-134. ISSN 2349-0373. www.arcjournals.org.

Hariyani,S. Ahmad,N.J.\&Marsitin,R. (2021). Mathematics teaching practicum for junior high school in a different culture-based situation. The Universal Academic Research Journal,3(2),77-86.

Immaculate, E.E. (2005). The funding needs of vocational and technical education programmes in Nigeria school system. JONATT, 5(1), 18-21

Jang, E.E., (2008). A framework for cognitive diagnostic assessment. In C. A. Chapelle, Y. R. Chang, \& J. Xu (Ed). Towards adaptative CALL. National language processing for diagnostic language assessment (pp. 117-131). Ames, IA; Iowa State University.

Karagöz,S. (2021). Evaluation of distance education: The sample of guidance and counseling students. The Universal Academic Research Journal,3(1),18-25.

Lina, Vyas (2004). Delivering better government: Assessing the Effectiveness of public service training in India. Public personnel management. 33(3), 291-306.

Lynch, M. (2018). The real purpose of assessment in education. https://www.theadvocate.org/real-purposeassessment-education

Okpala, P.N., Onocha, C.O. \& Oyedeji, O.A. (1993). Measurement and evaluation in education. Stirling-Hoden publishers Nig. Ltd.

Onuka, A. O. U. \& Akinyem, T. F. (2011). Assessment as a tool for learning improvement at secondary education level. Revolutionising Assessment and Evaluation Procedures in Education. A book of reading in honour of Professor Promise N. Okpala Stirling- Horden Publishers Lt., 37- 52.

Onuka, A. O. U. \& Durowoju, E. O. (2011, August 8-12). Continuous assessment for improved higher education learning achievement in business management [paper presentation]. HERPNET.

Onunkwo, G. I. N. (2002). Fundamentals of education measurement and evaluation. Owerri; Cape publishers International.

Onuogha, G.N., (2011). Educational evaluation: A panacea for human capital development. Nigerian Journal of Educational Research and Evaluation, 10(3), 156-164. ISSN 0795-3607

Yoloye, E.A. (2008). Fundamentals of educational evaluation. Stirling-Horden Publishers Ltd. 